barium meal three days after admission suggested a shallow erosion high on the posterior aspect of the lesser curve of the stomach. Clinically there was no evidence of further bleeding. He was started on soluble insulin and timed blood sugars were in the range of $150-175 \mathrm{mg} / 100 \mathrm{ml}$.

Ten days after admission fibreoptic gastroscopy under intravenous diazepam ${ }^{3}$ was performed by one of us (R.H.F.). The gastric mucosa was studded with punctate areas compatible with a diffuse gastritis. The pylorus contracted normally with some bile reflux and no evidence of ulceration was seen.

At follow up in another hospital five and a half weeks later, our patient was well and free of any gastric symptoms. His diabetes had been difficult to manage, with hypoglycaemic attacks on soluble insulin 12 units in the morning, 8 units each evening, and a $200 \mathrm{~g}$ carbohydrate diet. He had gained 6.1 $\mathrm{kg}$ in weight.

We suggest that this patient's anorexia, epigastric discomfort and pain, weight loss, and ultimate gastric haemorrhage were due to overdosage with phenformin.-We are,

Area Centre for Neurology,

Royal Surrey County Hospital,

Guildford, Surrey

N. R. T. PAShLEY

St. Luke's Hospital,

Guildford, Surrey

1 Personal Communication.

Fearnley, G. R., Chakrabarti, R., and Evans, J. F., Lancet, 1971, 1, 723.

ospital Medicine, 1971, 6. (November Equipment Supplement).

\section{Sickle-cell Trait and Altitude}

SIR,-Dr. R. L. Green and others (4 December, p. 593) have misquoted and disputed a statement that appeared in my book. ${ }^{1}$ The gist of the statement as originally made was that individuals with sickle-cell trait should not be allowed to enter a career involving flying, but that those aircrew, already trained and subsequently found to have sickle-cell trait, should be allowed to continue flying under medical supervision Dr. Green and his colleagues substituted the word "patient" for "individual." Elsewhere in my book, which they have quoted, it is clearly stated that sickle-cell trait is an abnormality but not a disease; hence the term individual is appropriate and the term patient is misleading.

Dr. Green and colleagues then commented that "There seems to be little logic in this argument, which presumably advocates rejection of new entrants with the sickle-cell trait on the grounds that they may represent a safety risk. To retain those already trained, though superficially humane, seems to ignore this implied risk, and it is difficult to reconcile the two attitudes." They stated further that "It would seem most important that some firm, lasting, and internationally acceptable policy be defined on this subject by authorities responsible for licensing."

The logic in my statement is that unless and until there is sufficient evidence that sickle-cell trait is an important risk to flyers, and until an internationally acceptable policy is defined, it would be more sensible to recruit aircrew that do not have sicklecell trait, but it would be unfair, wasteful, and foolish to ground experienced personnel. In all of the medical literature, including that cited by Dr. Green and his colleagues, there is not a single case of mishap associated with sickling in a member of an aircrew.

Non-recruitment of aircrew with sicklecell trait is a protection against arbitrary action by individuals who may have, or be influenced by, an attitude which was expressed by Dr. Green and colleagues. This attitude is shown in the statement that "The sickle-cell trait is no longer an important risk in most commercial flights, but if, as on certain African routes, a Negro traveller must take an unpressurized aircraft it would be wise to ascertain the sickling status before departure." The statement implies that it is chiefly in Africa that there are commercial flights on unpressurized aircraft, and that sickling is found only in "Negroes." These implications are refuted by data collected by other workers, some of which are cited by Dr. Green and his colleagues-that is symptoms arising after flights in America, and symptoms of sickling in a Sicilian youth.

The suggestion that "all passengers and aircrew who might have some form of sickle-cell disease should be screened before flight" is a reductio ad absurbum of the authors' attitude which is belied by a statement in the same paragraph of the article which reads in part "patients with sicklecell anaemia seem to be able to fly in pressurized aircraft with little risk."-I am, etc.,

Roger A. Lewis

Department of Pharmacology,

University of Ghana Medical School,

Accra, Ghana

1 Lewis, R. A., Sickle States: Clinical Features in West Africans. Accra, Ghana Universities Press, 1970 .

SIR,-In their article about the sickle-cell and altitude, Dr. R. L. Green and his colleagues suggest that "the only way to avoid this situation [of an in-flight incident] would be to set up a screening system available to all Negro travellers, which would detect not only the presence of sickle haemoglobin but specifically cases of undiagnosed sickle-cell haemoglobin $\mathrm{C}$ disease, sickle-cell thalassaemia, and the unusual clinically benign cases of sickle-cell anaemia with persistent splenomegaly."

What the authors do not seem to know is that not only Negroes have the sickle-cell gene. ${ }^{12}$ In some parts of Greece the prevalence of the sickle-cell trait is $30 \% ;^{3}$ more than twice the prevalence in Northern Ghana. The forebears and descendants of these non-Negro possessors of the sickle-cell gene are, doubtlessly, scattered over America and Europe today. How can we identify them, from their external features, to thrust upon them the "benefits" of this advice? Surely the authors would not advocate that we deny some sections of the world community the benefits of their suggestion.

The authors come nearest to the heart of the problem of sickle-cell disorder when they state that, "Many patients from the sicklecell clinic ... often travel by air to the United States and an infarctive episode during flight has never been recorded." The disconcerting fact is that it is still not fully known why some "sicklers" have infarctive crises (or any other crises) out of the blue, at sea level, when they do have these crises. Conversely, it is still not fully known why some "sicklers" whom one might have expected to have crises at certain times in certain circumstances remain quite asymtomatic.

If we applied the suggested screening test to all passengers (black and white) who disembark after a flight having had no symptoms whatsoever, it would be educative to know how many "sicklers" there would be among them. Also, if we screened all those passengers (black and white) who at disembarkation have had an in-flight symptom or incident, it would be educative to know how many "non-sicklers" there would be among them.-I am, etc.,

Military Hospital, Accra, Ghana

F. F. T. DJabanor

1 Choremis, C., Zervos, N., Constantinides, V., and Zannos, L., Lancet, 1951, 1, 1147.

3 Deliyannis, G. A., and Tavlarakis, N., British Medical fournal, 1955, 2, 299.

\section{Mortuary Technicians}

SIR,-Dr. C. F. Ross (18 December, p. 751) raises a very valid point by drawing attention to the shortage of mortuary technicians. There are, however, other difficulties in coping with the anticipated increased number of necropsies carried out on behalf of H.M. Coroners.

In this county, for example, the bulk of the forensic work (some 750 necropsies a year) is at present undertaken by a freelance specialist forensic pathologist who travels to the various public mortuaries. If in future these necropsies are to be carried out by N.H.S. morbid anatomists, where is this work to be done? If at two or three hospital centres with adequate facilities, who will pay for the transport of perhaps 1,000 bodies a year over distances up to perhaps 80 miles $(128 \mathrm{~km})$ a round trip at presentday prices? If they are to be done, as at present, in public mortuaries scattered over the county, which measures some 75 miles $(120 \mathrm{~km})$ in length, who will be doing the N.H.S. work while the morbid anatomists are absent on their travels? -I am, etc.,

Department of Histopathology,

R. SALM

Royal Cornwall Hospital, Truro, Cornwall

\section{Need for Asylums}

SIR,-What does not seem yet to be recognized is the need for rest-houses, retreats, or (to use an oldfashioned word) asylums for ordinary everyday people when temporarily bowled over by the stresses and pressures of life today. In some areas there are "halfway" houses, in which ex-patients from mental hospitals can be rehabilitated and resocialized before re-entry into the rat-race; but, although there are scores of Samaritan "crisis" centres, there are no residential sanctuaries for those who are heading towards mental or emotional breakdown: people who need to get away from it all for a spell, from their families, their friends, their jobs, their problems, and to be granted a respite in which to sort themselves out.

Some may urgently need psychiatric treatment. Most do not. They merely want to withdraw from their crisis, and get their troubles off their chests to anyone who will listen compassionately and help them get things back into proportion. In any case professional psychiatric aid is rarely immediately available. 